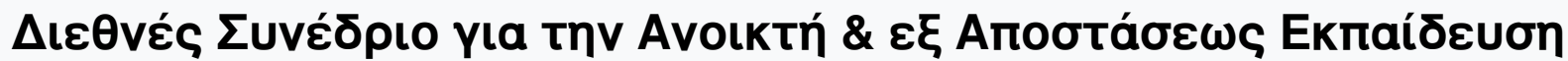

Tóp. 7, Ap. 2A (2013)

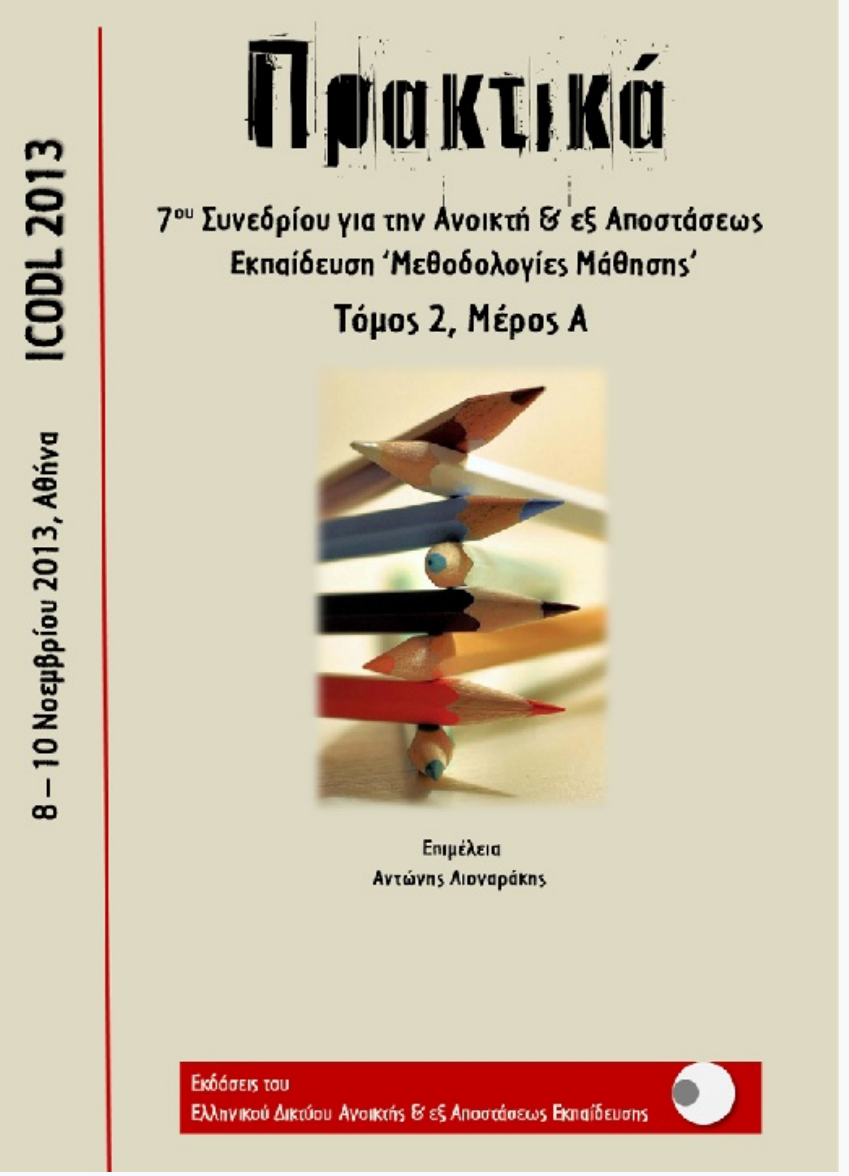

Action Research on Using Flipped Classroom Principles to Teach Upper High School Biology

Alexandra Kouloumbaritsi, Eva Dimitroglou, Evangelia Mavrikaki, Dia Galanopoulou

doi: $10.12681 /$ icodl. 571 


\title{
Action Research on Using Flipped Classroom Principles to Teach Upper High School Biology
}

\author{
Kouloumbaritsi Alexandra \\ National and Kapodistrian University of Athens \\ Phd. Educational Technology \\ acoul@otenet.gr \\ Evangelia Mavrikaki \\ National and Kapodistrian University of Athens \\ Assistant Professor \\ emavrikaki@primedu.uoa.gr
}

\author{
Eva Dimitroglou \\ Greek Ministry of Education \\ Secondary School Biology Teacher \\ eva.dimitroglou@gmail.com
}

\author{
Dia Galanopoulou \\ National and Kapodistrian University of \\ Athens \\ Associate Professor \\ galanopoulou@chem.uoa.gr
}

\begin{abstract}
This paper reports on the design of Action Research on using the Flipped Classroom Model to teach the chemical composition of the cell unit to two $11^{\text {th }}$ grade classrooms of a school in a south low to middle class area of Athens. Two more classes are used as a control group. The Flipped Classroom Model suggests lessons should be delivered at home through video lectures while homework is conducted at school by having students working and discussing in groups to clarify ideas, solve problems and make queries. Research questions concern the extent to which Flipped Classroom can influence to a statistically significant level student motivation and achievement.
\end{abstract}

\section{Terms definition}

A. The Flipped Classroom Model turns teaching to its head by delivering lectures at home via teacher made videos and by moving homework during class work time. Both activities are common, however they are seen under a fresh and novel perspective. Doing "homework" at school allows students to make queries, clarify concepts and processes, solve problems and develop ideas by working in pairs and in groups, thus creating a cooperative learning environment. It also encourages the teacher to work with students on a one to one basis, thus supporting personalized instruction. Interaction and discussion among students and students and teacher are conducive to the success of the flipped method.

B. Educational Action Research (Carr \& Kemmis, 2002, pp. 164-165) is a term used to describe a family of activities in curriculum development, professional development, school improvement programs and systems planning and policy making. These activities have in common the identification of strategies of planned action, which are implemented, and then systematically submitted to observation, reflection and change. Action Research aims at the improvement of three areas: firstly the improvement of practice, namely action. Secondly, the improvement of the understanding of the practice by its practitioners, and thirdly the improvement of the situation in which the practice takes place. Minimum requirements for action research to succeed are three: firstly, the project takes as its subject-matter action susceptible of improvement, secondly the project proceeds as a spiral of cycles of planning, acting, observing and reflecting actions (Habermas, 1974) interconnected and inter 
depended, and thirdly, the project involves all its practitioners in a long widening community.

\section{The Status of Biology in Secondary Education in Greece}

Greek secondary school biology is compulsory in grades 7, and in grades 9 through 12. School biology is under -represented in Greek curriculum because it is taught in one class period every week. It is not uncommon for students to miss out classes due to causes of force majeure, such as austerity measures (i.e. a biology teacher that is not placed on time), or organizational and other reasons (i.e. educational visits organized by the school). Depending on the direction of higher education studies chosen by a student, biology curriculum may vary from surface to deep. Therefore, there is great need to give instructional time for having students imposing and responding to higher order questions, to undertake inquiry based laboratory exercises and group activities.

\section{Research questions}

There is currently a growing literature concerning students' interest in science (Baram-Tsabari \& Yarden, 2007; Hidi \& Harackiewicz, 2000). Zacharia and Barton (2004, p. 199) suggested that "attitudes (towards science) are affected by students' interest levels, the curriculum and the learning climate". The latter (the way biology is taught - transmissive pedagogy, teacher-centered usually) according to Lyons (2006) may affect the perceived difficulty of biology which in turn affects students' attitudes towards biology.

Mavrikaki et al. (2012) showed that Greek high school students have neither positive nor negative attitudes towards biology and suggested that this may be attributed, among others, to the way biology is taught in the Greek High School. The same goes regarding their motivation (Andressa, Mavrikaki \& Dermitzaki, under review) towards biology.

The above mentioned led us to wonder if the implementation of the Flipped Classroom model in school biology improve Greek high school students' motivation and attitudes towards biology and if an implementation of the Flipped Classroom model in school biology would improve Greek high school students' achievement in biology. In order to answer the above first we have to answer the following:

- Which are the instructional and classroom management considerations while preparing FC biology lessons?

- Do FC instructional principles and approaches fit in Greek upper high school practices?

\section{Research Design}

This study focuses on student motivation and attitudes (more enthusiasm, more participation during school work and homework) and on the improvement of achievement towards school biology by using the Flipped Classroom model. It will take place during the fall semester 2013 in two biology classrooms (experimental group), in a school located in the south area of Athens where students are coming from a low to moderate income community. The teacher (the second of the authors of this paper) will implement the Flipped Classroom model to teach the chemical composition of the cell unit, namely, biological macromolecules -nucleic acids, proteins, lipids and carbs. The same content will be taught to two control-group biology classrooms which run in the same school. Experimental group and control group students are $11^{\text {th }}$ grade students ( $\mathrm{N}=120$ approx.).

Volume 2 - Section A: theoretical papers, original research and scientific articles 
Students of both groups will be accommodated according to statistical similarity. A ttest will be implemented on both groups to assure that the experimental and the control group comprise of students having similar characteristics, for instance, students perform at the same achievement rate based on their reported grades and share similar attitudes and motivation towards school biology. Both groups will be given pre-tests (before video lectures and classroom discussions) and post tests.

All biology students will have a digital classroom account on Edmondo (www.edmodo.com) where video lectures will be posted and be accessible 24 hours a day 7 days a week. To accommodate students without Internet or computer access outside of school, videos are made available on USB Flash drives or put onto DVDs for students to check out and take home. The homework lectures will be assigned one week in advance of the due date so students can make arrangements to use school computers before or after school. Student access will not be a factor that will affect the results of this study.

As students watch each VIDEO lecture (Ctrl + click to watch the sample lecture) they will fill out notes and teacher made worksheets and return it to class on its due date. Students that do not complete the assignment as homework will have to miss out on the peer teaching groups and activity stations while they watch the video and take the missing notes during class. No credit will be awarded to students that did not complete the assignment as homework even though all students will be required to have notes over the material. Contrary to Haberman's (2012) research plan grades on worksheets and post tests are considered motivating factors for all students.

Students that watch the videos will be assessed by the return rate and quality of their notes and worksheets. Their homework will be assessed on a Likert type scale of one to four: $1=$ unacceptable, $2=$ basic, $3=$ proficient, $4=$ distinguished to track improvement. Rubrics will be developed with students' contribution in order to consistently measure their achievement rates on regular tests and their participation and quality of work during group work (Table 1).

Table 1. Group Participation Rubric

\begin{tabular}{|c|c|c|c|c|}
\hline Criteria & \multicolumn{3}{|c|}{ Level of Participation } & Unacceptable \\
\hline Workload & $\begin{array}{l}\text { Did a full } \\
\text { share of the } \\
\text { work-or } \\
\text { more; knows } \\
\text { what needs to } \\
\text { be done and } \\
\text { does it; } \\
\text { volunteers to } \\
\text { help others. }\end{array}$ & $\begin{array}{l}\text { Did an equal } \\
\text { share of the work; } \\
\text { does work when } \\
\text { asked; works hard } \\
\text { most of the time. }\end{array}$ & $\begin{array}{l}\text { Did almost as } \\
\text { much work as } \\
\text { others; seldom } \\
\text { asks for help. }\end{array}$ & $\begin{array}{l}\text { Did less work } \\
\text { than others; } \\
\text { doesn't get } \\
\text { caught up after } \\
\text { absence; doesn't } \\
\text { ask for help. }\end{array}$ \\
\hline $\begin{array}{l}\text { Getting } \\
\text { Organized }\end{array}$ & $\begin{array}{l}\text { Took the } \\
\text { initiative } \\
\text { proposing } \\
\text { meeting times } \\
\text { and getting } \\
\text { group } \\
\text { organized. }\end{array}$ & $\begin{array}{l}\text { Worked } \\
\text { agreeably with } \\
\text { partner(s) } \\
\text { concerning times } \\
\text { and places to } \\
\text { meet. }\end{array}$ & $\begin{array}{l}\text { Could be coaxed } \\
\text { into meeting with } \\
\text { other partner(s). }\end{array}$ & $\begin{array}{l}\text { Did not meet } \\
\text { partner(s) at } \\
\text { agreed times and } \\
\text { places. }\end{array}$ \\
\hline Participation & Provided many & Participated in & Listened mainly; & Seemed bored \\
\hline
\end{tabular}




\begin{tabular}{|c|c|c|c|c|}
\hline in Discussions & $\begin{array}{l}\text { good ideas for } \\
\text { the unit } \\
\text { development; } \\
\text { inspired } \\
\text { others; clearly } \\
\text { communicated } \\
\text { desires, ideas, } \\
\text { personal } \\
\text { needs, and } \\
\text { feelings. }\end{array}$ & $\begin{array}{l}\text { discussions; } \\
\text { shared feelings } \\
\text { and thoughts. }\end{array}$ & $\begin{array}{l}\text { on some } \\
\text { occasions, made } \\
\text { suggestions. }\end{array}$ & $\begin{array}{l}\text { with } \\
\text { conversations } \\
\text { about the unit; } \\
\text { rarely spoke up, } \\
\text { and ideas were } \\
\text { off the mark. }\end{array}$ \\
\hline $\begin{array}{l}\text { Meeting } \\
\text { Deadlines }\end{array}$ & $\begin{array}{l}\text { Completed } \\
\text { assigned work } \\
\text { ahead of time. }\end{array}$ & $\begin{array}{l}\text { Completed } \\
\text { assigned work on } \\
\text { time. }\end{array}$ & $\begin{array}{l}\text { Needed some } \\
\text { reminding; work } \\
\text { was late but it } \\
\text { didn't impact } \\
\text { grade. }\end{array}$ & $\begin{array}{l}\text { Needed much } \\
\text { reminding; work } \\
\text { was late and it did } \\
\text { impact quality of } \\
\text { work or grade. }\end{array}$ \\
\hline $\begin{array}{l}\text { Showing up } \\
\text { for Meetings } \\
\text { Score }\end{array}$ & $\begin{array}{l}\text { Showed up for } \\
\text { meetings } \\
\text { punctually, } \\
\text { sometimes } \\
\text { ahead of time. }\end{array}$ & $\begin{array}{l}\text { Showed up for } \\
\text { meetings on time. }\end{array}$ & $\begin{array}{l}\text { Showed up late, } \\
\text { but it wasn't a big } \\
\text { problem for } \\
\text { completing work. }\end{array}$ & $\begin{array}{l}\text { No show or } \\
\text { extremely late; } \\
\text { feeble or no } \\
\text { excuse offered. }\end{array}$ \\
\hline $\begin{array}{l}\text { Providing } \\
\text { Feedback } \\
\text { Score }\end{array}$ & $\begin{array}{l}\text { Habitually } \\
\text { provides } \\
\text { dignified, } \\
\text { clear, and } \\
\text { respectful } \\
\text { feedback. }\end{array}$ & $\begin{array}{l}\text { Gave feedback } \\
\text { that did not } \\
\text { offend. }\end{array}$ & $\begin{array}{l}\text { Provided some } \\
\text { feedback; } \\
\text { sometimes hurt } \\
\text { feelings of others } \\
\text { with feedback or } \\
\text { made irrelevant } \\
\text { comments. }\end{array}$ & $\begin{array}{l}\text { Was openly rude } \\
\text { when giving } \\
\text { feedback. }\end{array}$ \\
\hline $\begin{array}{l}\text { Receiving } \\
\text { Feedback } \\
\text { Score }\end{array}$ & $\begin{array}{l}\text { Graciously } \\
\text { accepted } \\
\text { feedback. }\end{array}$ & $\begin{array}{l}\text { Accepted } \\
\text { feedback. }\end{array}$ & $\begin{array}{l}\text { Reluctantly } \\
\text { accepted } \\
\text { feedback. }\end{array}$ & $\begin{array}{l}\text { Refused to listen } \\
\text { to feedback. }\end{array}$ \\
\hline
\end{tabular}

The third type of data being collected will focus on student opinions about the Flipped Classroom. Students will be asked to fill out Google form surveys (https://drive.google.com/start/apps ) so they can provide feedback as to what they like and dislike about the Flipped Classroom model. Interviews with random students from each class will also be conducted.

These data sources should show trends in student attitudes and motivation for watching video lectures as homework, taking notes and competing assignments. Some themes to look for during analysis include: knowledge, understanding, note taking skills, confidence and change in student opinions.

Each week as data is assessed, it will be posted on http://evadimitroglou.wordpress.com/ (in Greek and in English). This public blog will act as a research journal (teacher reflections according to Action Research design), reporting on observations and reflections on instructional actions taken, while providing a way for other educators to offer suggestions and guidance.

\section{Desirable (Expected) Outcomes}

For the students: Experimental group vs control group: Improvement of student motivation, homework participation and achievement and student attitude. 
For the teacher: Action research design may prove to be catalytic to personal growth of the teacher who designs and conducts innovative methods and reflects upon their impact on herself/himself and the students. This may lead to shared knowledge as the experience gained by the teacher - researcher may be passed on to colleagues, thus contributing to shared professional development (see Carr \& Kemmis, 2002; Haberman, 2012; Kouloumbaritsi, 2002).

For school biology: Flipped Classroom (FC) model may prove a powerful tool to boost student interest and achievement in biology. As reported by other researchers (i.e. see, Haberman, 2012), the initial enthusiasm of the students for FC may easily wane if less attention is given on student interaction and discussions concerning their inquiry work. Therefore more emphasis should be put on positive interdependence among students (see Johnson, Johnson \& Holubec,1994) and on the instructional alignment of video-lectures, worksheets and tests.

\section{Discussion}

Preparing and delivering Flipped Classroom (FC) lessons proved to be a quite courageous decision. The teacher who decides to implement the model needs to undertake a quite unfamiliar to Greek high school teachers project and a multi faceted one. FC assumes a mental collaboration between specialists of different backgrounds such as curriculum designer, instructional designer, subject expert and biology classroom teacher with experience on FC which is quite far from Greek school culture. In the review that we carried out in the present study we didn't find any Greek biology teacher with experience on FC. Youtube videos from global classrooms and worldwide experienced teachers on FC filled the gap.

The FC project is a highly demanding but rather rewarding one since it emancipates the teacher by transforming its role from a transmitter of ready-made materials to designer and highly motivated professional. However it is very time consuming to prepare and deliver FC lessons since all the material is teacher made and moreover students need to be trained by the teacher to undertake a more active role. Such teaching and learning functions lay at the center of Action Research (Carr \& Kemmis, 2002). Teaching and learning turns out to be student's responsibility, and collaboration and reasoning are among the principal goals and means of learning. These are two of the main goals in the new science curriculum for upper high school in Greece. It remains to be seen whether FC can be an effective pedagogical vehicle for the fulfillment of the aspirations of the Upper High School New Curriculum in Greece.

\section{References}

Andressa, H., Mavrikaki, E., \& Dermitzaki, I. (under review). Greek students' motivation towards biology. International Journal of Science Education.

Alevizaki, E., (2008). Rubrics for Student Assessment in Cooperative Learning Environments. University of Peiraias: Unpublished MA Dissertation.

Baram-Tsabari, A., \& Yarden, A. (2007). Interest in Biology: A developmental shift characterized using self-generated questions. The American Biology Teacher, 69(9), 532-540.

Carr, W., \& Kemmis, S. (2002). Becoming Critical: Education, Knowledge and Action Research. London: Routledge Falmer.

Habermas, J. (1974). Theory and Practice (transl. J.Viertel). London: Heinemann.

Haberman, Mrs. (2012). My flipped Classroom Action Research Plan. Retrieved in 1/6/2013 from

http://myflippedclassroomexperience.blogspot.gr/2012/02/my-flipped-classroom-action-research.html 
Hidi, S., \& Harackiewicz, J.M. (2000). Motivating the academically unmotivated: a critical issue for the 21st century. Review of Educational Research, 70(2), 151-179.

Johnson, D.W., Johnson, R.T. \& Holubec, E. (1994). Circles of Learning. Cooperation in the Classroom. Alexandria: ASCD.

Kouloumbaritsi, A. (2002). Flexible Zone Changes School: A Case Study of Cooperative Processes and Mutual Commitments. Educational Review, 6, 57-79.

Lombardi, M.M. (2008). Making the Grade: The Role of Assessment in Authentic Learning. Retrieved in 10/6/2013 from http://www.educause.edu/ir/library/pdf/ELI3019.pdf

Lyons, T. (2006). Different Countries, Same Science Classes: Students' experiences of school science in their own words. International Journal of Science Education, 28(6), 591-613.

Mavrikaki, E., Koumparou, H., Kyriakoudi, M., Papacharalampous, I., Trimandili, M., \& (2012). Greek secondary school students' views about biology. International Journal of Environmental and Science Education, 7(2), 217-232.

Zacharia, Z., \& Barton, A.C. (2004). Urban Middle-School Students' Attitudes Toward a Defined Science. Science Education, 88(2), 197-222.

For sample video - $\quad$ lecture, see:

https://docs.google.com/file/d/0B0naVa93v_UTU2dqRnF2RHdMQTQ/edit 